\title{
Scientific Study of Sociological Problem: Solve the Begging \& Poverty Problem in Iraq
}

\author{
Muayad Baqer Mohammed Alfahham M.Sc \\ Lecturer in Contemporary Islamic History Field \\ Department of Power Mechanics \\ Najaf Engineering Technical College, Alfurat Al-awsat Technical University, Iraq \\ E-mail: coj.muy@atu.edu.iq \\ Afaq Jaber Kadhium M.Sc \\ Lecturer, Department of Chemistry \\ Faculty of Education, Kufa Univeristy, Iraq \\ E-mail: dr.nagham_mj2@yahoo.com \\ Hanan Ali Hussein M.Sc \\ Assistant Professor, Department of Mathematics \\ Faculty of Education for Girls, Kufa University, Iraq \\ E-mail: hanansmadi@hu.edu.jo \\ Jalal Hasan Mohammed M.Sc \\ Lecturer, Department of Pharmaceutical Chemistry \\ College of Pharmacy, Karbala University, Karbala, Iraq \\ Manar Ghyath Abd Almutalib Almosawy \\ Lecturer in Chemistry, Imam Jafar Al-Sadiq University, Najaf, Iraq \\ Nagham Mahmood Aljamali $P h D$ \\ Assistant Professor, Organic Synthetic Chemistry, Department of Chemistry \\ University of Kufa, Iraq \\ E-mail: dr.nagham_mj@yahoo.com
}

\begin{abstract}
This Case study to Solve social problem like The begging in street and poverty problem for small cities., This study investigated the prevalence and consequences of street begging among adults and children in small towns, Descriptive of this scientific study was adopted for the many cases in many small and poor towns and Finding solutions Of The Begging Problem :

Name Problem: Treatment of Social problem (The Begging)

Type of Study: Scientific Study for Treatment of Social Problem (The Begging)

Aim of Scientific Study: Finding solutions of The Begging Problem

Keywords: The Begging, Poverty Problem, Scientific Study, Case Study, Social Problem.

\section{Introduction}

The Begging stays the repetition of beseeching others to contribution approval, often ability of charge, with diminutive or no prospect of complementation. A creature doing like it is termed a panhandler or beggar. Beggars may be located or found in common places like transport routes, urban grounds, plus markets. In addition to money, they may besides ask to food, drink
\end{abstract}


(Ogunkan , 2009), or other small things. Internet begging is the contemporary approach of requesting people to provide money to others thru the Internet, rather than in somebody. Internet begging is commonly directed at people (Namwata, 2012) who are conversant through the beggar, while it may be promoted to foreigners. Internet begging comprehends requirements to assist meeting basic needs like medicinal care with shelter, as well as requirements to all people (Muayad B, 2020) to wage for vacations, school trips, besides to other belongings that the beggar requirements while cannot contentedly afford

\section{I.I Causes of the Begging and Poverty Problem}

The phenomenon of begging is the outcome of a many of reasons, like:

\section{I.I.I Poverty Problem}

Physical debility, national disaster ,religion, culture, civil .,at the contemporaneous time, has been encrustation two greatest vital complications like: the first one is to come across the swelling demand aimed at food with other requests merchandises (Demewozu, 2005), plus to the second is exhausting the prevalent poverty via the ever increasing population. And there is no Population and Housing.

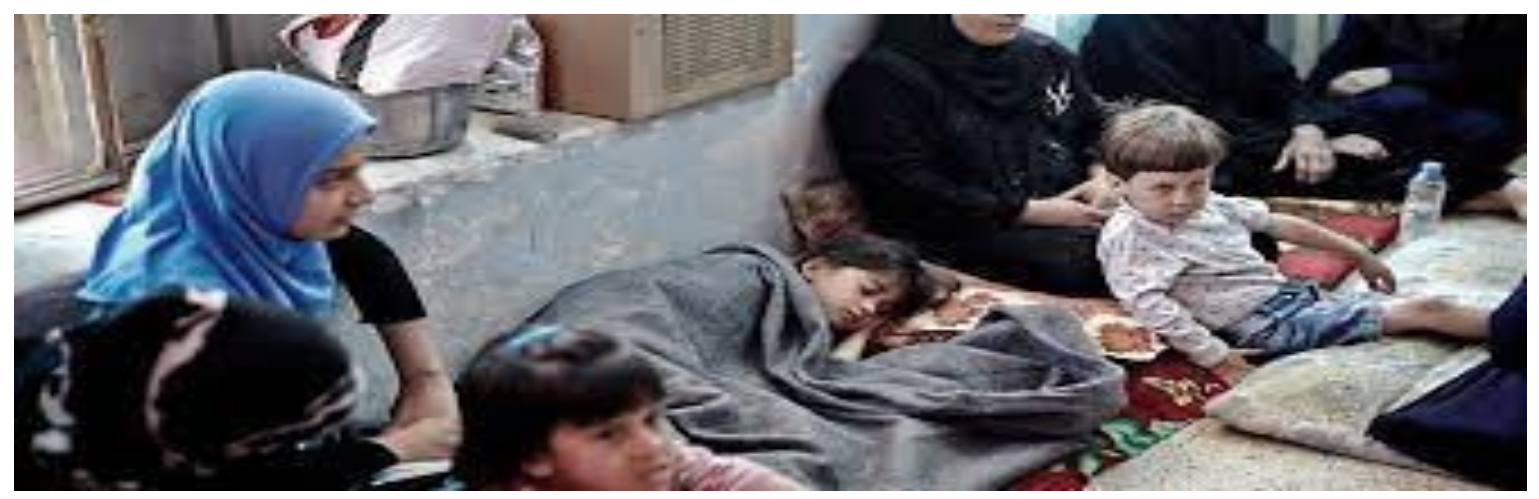

Figure I. Problem of Population and Housing

Iraq is a republic that has been exhausted through Fighting and wars, approvals and violence thru the latter four decades. It goes deprived of saying that these disasters would dispensation behind a society grief from grim contests to its social safety (Hung, 2016).

\section{I.I.2 Decreasing of Government' Services}

Government of Iraq should offer and provide numerous services like free education, scholarship for children (Powers, Martin. 2019), mealtime, house place, helping card, source of water, electricity, etc.

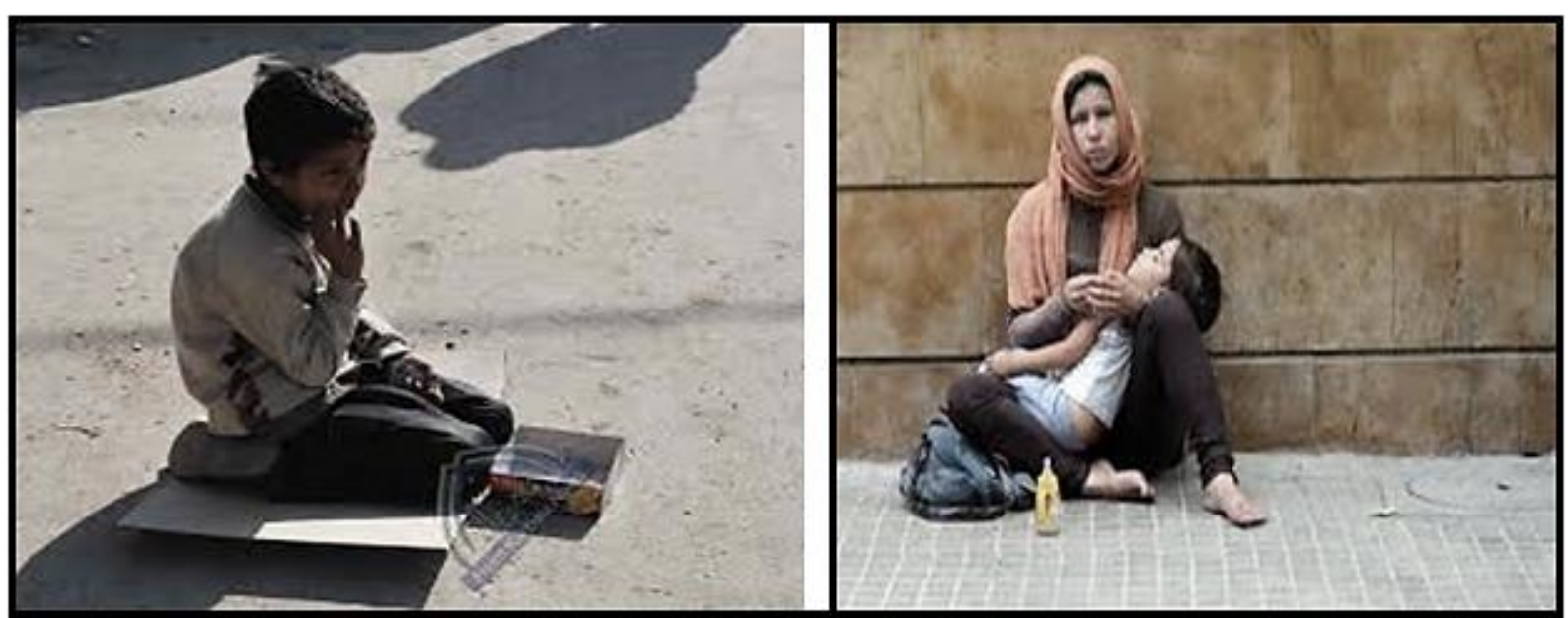

Figure 2. Problem of Services 
I.I.3 War, Fighting, Violence besides Terrorism

Iraq is a republic that has been exhausted through Fighting and wars, approvals and violence thru the latter four decades. It goes deprived of saying that these disasters would dispensation behind a society grief from grim contests to its social safety (Hung, 2016).

2. Data Analysis of the Begging in Iraq

These differences statistical studies will assist us to state each problem of the beginning and poverty to its solution in better precision. We are worried mainly with the logical poverty and beginning. It will solitary rarely accord with the fundamental, temporal, or exposed beginning, while it is frequently the expositional beginning (Johnsen \& Fitzpatrick, 2010). In the flowing data (tables and analysis) (Dromi, 2012):

Table. I. Education Indicators in Iraq in Comparison to Other Countries according to (UNDP, Human Development Report 2014: Reducing Vulnerabilities and Building Resilience)

\begin{tabular}{|l|l|l|l|l|}
\hline \multicolumn{1}{|c|}{ Indicator } & \multicolumn{1}{|c|}{ Year } & \multicolumn{1}{c|}{ Iraq } & $\begin{array}{c}\text { Arab } \\
\text { World }\end{array}$ & $\begin{array}{c}\text { The } \\
\text { World }\end{array}$ \\
\hline Literacy Rates Amongst Adults & $2005-2012$ & 78.5 & 77.0 & 81.2 \\
\hline Literacy Rates Amongst Adolescents & $2005-2012$ & 82.4 & 89.9 & 87.9 \\
\hline Rate of Enrolment in Primary School & $2003-2012$ & 107.0 & 105.0 & 108.0 \\
\hline Rate of Enrolment in Secondary School & $2003-2012$ & 53.0 & 76.0 & 74.0 \\
\hline Rate of Enrolment in Higher Education & $2003-2012$ & 16.0 & 28.0 & 31.0 \\
\hline
\end{tabular}

Source: Powers, Martin (2019). China and England: The Preindustrial Struggle for Justice in Word and Image.

New York: Routledge. p. I75. ISBN 978-II38504035.

Table 2. Health Indicators in Iraq in Comparison to Other Countries according to UNDP, Human Development Report 20I4: Reducing Vulnerabilities and Building Resilience

\begin{tabular}{|l|c|c|c|c|}
\hline \multicolumn{1}{|c|}{ Indicator } & Year & Iraq & $\begin{array}{c}\text { Arab } \\
\text { World }\end{array}$ & $\begin{array}{c}\text { The } \\
\text { World }\end{array}$ \\
\hline Infant Mortality Rate & 2012 & 28 & 28 & 35 \\
\hline Mortality Rate for Children (5+ yrs) & 2012 & 34 & 37 & 47 \\
\hline $\begin{array}{l}\text { Adult Females Mortality Rate (for Every 1000 } \\
\text { Individuals) }\end{array}$ & 2011 & 116 & 111 & 127 \\
\hline $\begin{array}{l}\text { Adult Male Mortality Rate (for Every 1000 } \\
\text { Individuals) }\end{array}$ & 2011 & 207 & 116 & 188 \\
\hline $\begin{array}{l}\text { Malnutrition Amongst Children (Moderate or } \\
\text { Severe Stunting) }\end{array}$ & $2008-2012$ & 22.6 & 27 & - \\
\hline Severe or Moderate Obesity Amongst Children & $2008-2012$ & 11.8 & - & - \\
\hline
\end{tabular}

Source: Powers, Martin (2019). China and England: The Preindustrial Struggle for Justice in Word and Image. New York: Routledge. p. I75. ISBN 978-II38504035.

3. Solutions of the Begging and Poverty Problem

There are a few solutions around how to break and stop the begging and poverty, but major factor, it is important to recognize the backgrounds of the difficulties and problems which cause begging and poverty. Since different states have various causes for poverty, there will certainly not be a single clarification for all. However, these some actions can do a lot to relieve poverty anywhere: 


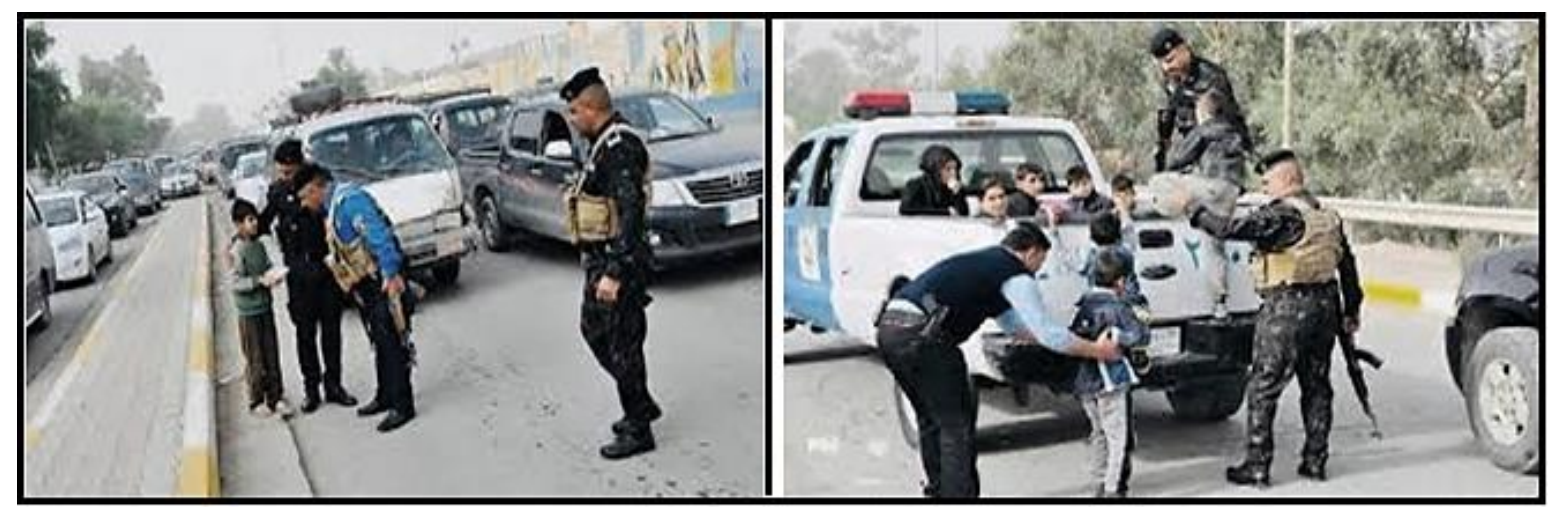

Figure 3. Decreasing of The Begging of Children in Iraq

\section{Development of Education Systems}

In Iraq, the education system is run via the Ministry of Education with Higher Education. According to the reports of (UNESCO ), Iraq was in the history before the first Bight War, in I99I had an educational system that was one of the best educational systems in the region and has won two prizes from the organization and Iraq become a country free of illiteracy, after a wide campaign to eradicate illiteracy which was begun in the seventies of the last century, where the proportion of primary school enrollment was via nearly $\mathrm{I} 00 \%$, besides to a high proportion of those who were able to read and write, while the governments that came after the occupation have neglected the education intentionally to serve the interests of Regional and global forces where they view of Iraq's progress as a threat to the chances of hegemony.

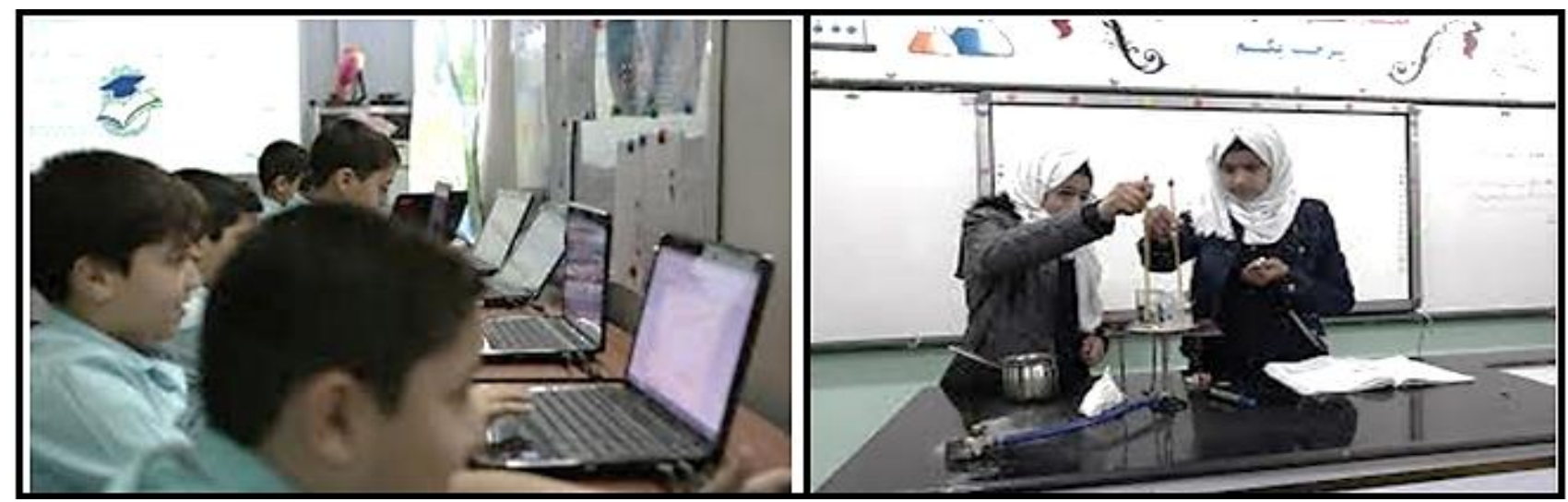

Figure 4. Development of Education Systems in Schools

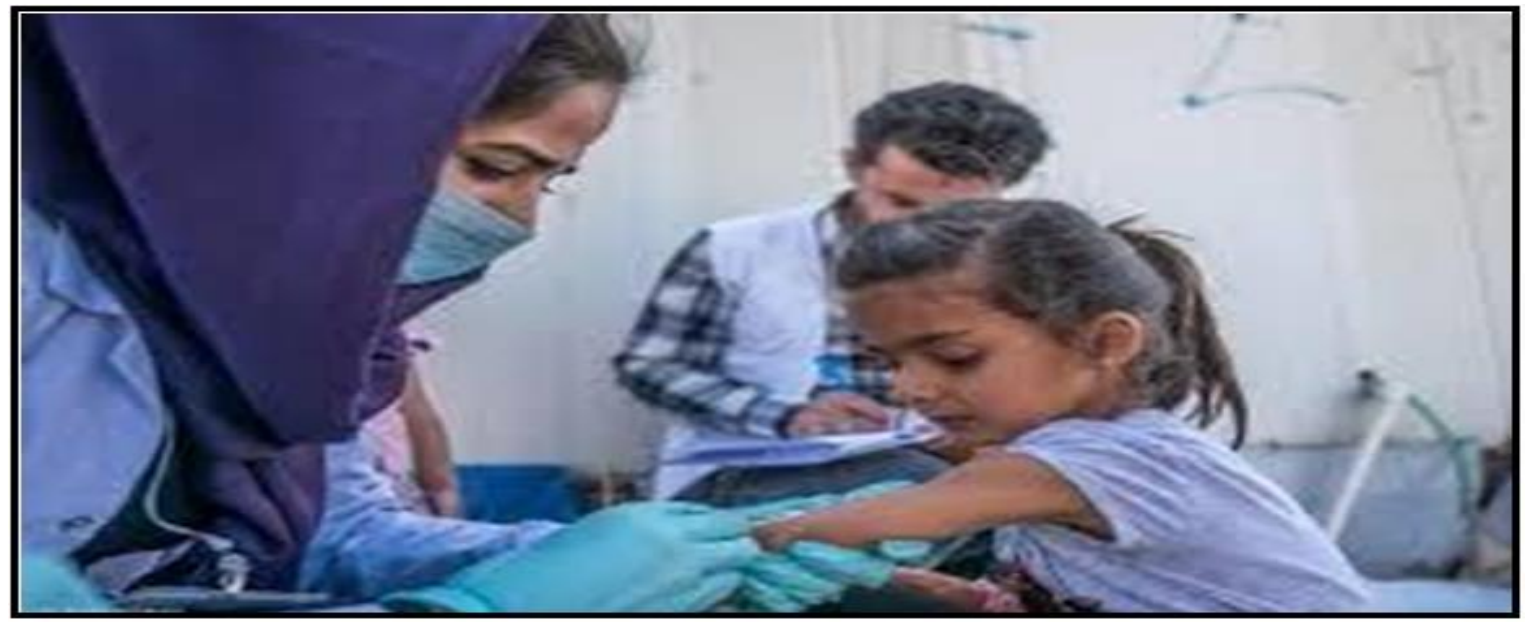

Figure 5. Development of Health Service for Children Health 


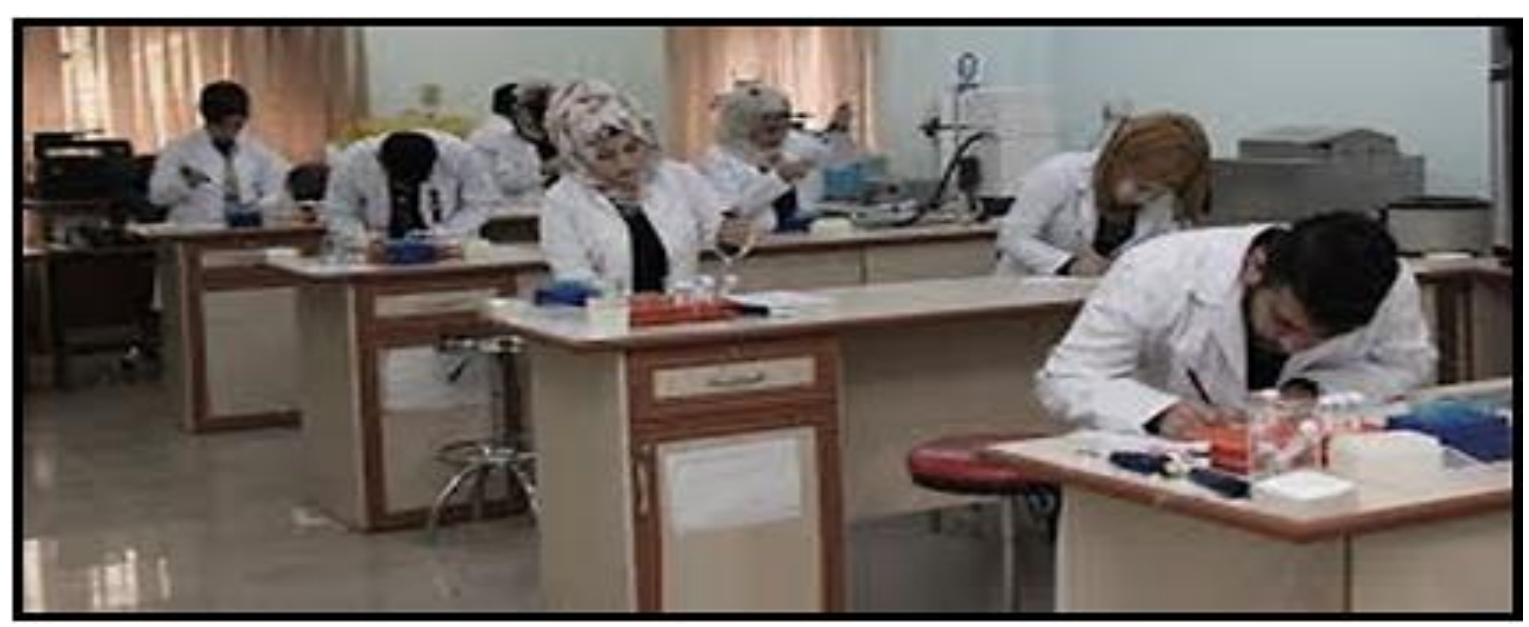

Figure 6. Development of Education Service

\section{Conclusions}

The greatly campaigned nature of social protection databases in Iraq takes exaggeration of their arrangement, expressly with affections to apparatuses applied to recognize target publics. It has besides led to the occurrence of many competing sources, like the National Nourishment of Allowances with the Ministry of Lab-out with Social Affairs

\section{References}

Dromi, Shai M. (2012). "Penny for your Thoughts: Beggars and the Exercise of Morality in Daily Life". Sociological Forum. 27 (4): 847-87I. doi:I0.I I II/j.I573-786I.2012.01359.x.

Demewozu W. (2005). Begging as a means of livelihood: conferring with the poor at the orthodox religious ceremonial days in Addis Ababa. African Study Monographs, Suppl. 29, I85-I9I.

Hung, Hing Ming. (2016). From the Mongols to the Ming Dynasty : How a Begging Monk Became Emperor of China, Zhu Yuan Zhang. New York: Algora Publishing. pp. 2I-22. ISBN 978I62894I524.

Johnsen \& Fitzpatrick, S. \& S. (2010). "Revanchist Sanitisation or Coercive Care? The Use of Enforcement to Combat

Begging, Street Drinking and Rough Sleeping in England". Urban Studies. 47 (8): I703-I723. doi :I0.II77/0042098009356I28 .

Muayad Baqer Mohammed Alfahham \& Muayad B M. (2020). Review on Religious Extremism in Islamic History (Previously and Contemporary). Forefront Journal of Humanities \& Social Science, Volume 2, Issue I, Jan 2020, 9- 18 .

Muayad Baqer Mohammed Alfahham . (2020). The Spread of Terrorism in Contemporary Islamic History with Comparison between Past and Present. Journal of Xi'an University of Architecture \& Technology.

Muayad Baqer Mohammed Alfahham, Muayad B M. (2020). Historical Study of the Results of the American War on Iraq Between (2003- 2020). International Journal of Psychosocial Rehabilitation.

Namwata BM L, Mgabo MR \& Dimoso P. (2012, June). Categories of street beggars and factors influencing street begging in central Tanzania. African Study Monographs 33(2),I33-I43.

Ogunkan DV \& Fawole OA. (2009). Incidence and socio-economic dimensions of begging in Nigerian cities: The case of Ogbomoso. International NGO Journal 4(I2), 498-503.

Powers, Martin. (2019). China and England: The Preindustrial Struggle for Justice in Word and Image. New York: Routledge. p. I75. ISBN 978-II38504035.

\section{Copyrights}

Copyright for this article is retained by the author(s), with first publication rights granted to the journal. This is an open-access article distributed under the terms and conditions of the Creative Commons Attribution license (http://creativecommons.org/licenses/by/4.0/). 